\title{
DATING THE END OF THE NEOLITHIC IN AN EASTERN SAHARA OASIS: MODELING ABSOLUTE CHRONOLOGY
}

\author{
Michel Wuttmann ${ }^{1} \cdot$ François Briois $^{2}$ • Béatrix Midant-Reynes ${ }^{3} \cdot$ Tiphaine Dachy $^{4}$
}

\begin{abstract}
The Neolithic site KS043, excavated by the Institut français d'archéologie orientale (IFAO), is situated in the southern basin of the Kharga Oasis (Egypt). It is one of the very few stratified prehistoric sites of the eastern Sahara. The archaeological remains were found near artesian springs that provided water for pastoralists during the dry Middle Holocene. In situ settlement features provided well-preserved material (charcoal, ashy sediment, ostrich eggshell) sufficient to perform radiocarbon dating in the IFAO laboratory in Cairo by the conventional liquid scintillation method. In 2 cases, ostrich eggshell and charcoal within the same in situ context gave significantly different results of, respectively, $\sim 600$ and $\sim 1200$ yr younger dates for the ostrich eggshells. The strong discrepancy is here highlighted for the first time and we suggest that it may be linked with postdepositional phenomena in the vicinity of the artesian springs. A thorough review of ${ }^{14} \mathrm{C}$ dates available for the Holocene in eastern Sahara shows that ostrich eggshells have been widely used. They seem slightly more prone to be discarded than other material but were never the object of a particular study in this context. Bayesian modeling shows that the Neolithic occupation at site KS043 spans a range from 5000 to 3950 cal BC (and concentrated around $4600-4350$ cal BC). Characteristic flint tools and pottery relate this occupation to the end of the Neolithic and show links with the Tasian culture, confirming the timing of the presence of this cultural complex in the desert before its appearance in the Nile Valley.
\end{abstract}

\section{INTRODUCTION}

Knowledge of the prehistoric eastern Sahara and the Nile Valley has been completely renewed during the past $30 \mathrm{yr}$ as a result of the intensive research conducted by international teams in those areas (Figure 1). These works were conducted on a large scale by American teams between 1973 and 1980 and 1990 and 2000 at Nabta Playa, Bir Sahara, and Bir Tarfawi, but also in the Dakhleh and Kharga oases (Wendorf and Schild 1980, 2001, 2004). The University of Cologne headed other major projects in the eastern Sahara (BOS, 1970-1995, Kuper 1989; and ACACIA, 1995-2000), focusing on archaeological and environmental approaches (Kuper 2006). In addition, programs were developed in the oases of Bahariya and Farafra since 1975 (Barich and Hassan 1984-1987; Alessio et al. 1992) and in the Dakhleh Oasis since 1980 (MacDonald 1999). These studies led to the recognition of regional chronological sequences of human occupation linked with climatic phases validated by numerous radiocarbon dates. Research undertaken over the last decade by the IFAO in Kharga Oasis are within the frame of this general dynamic (Briois et al. 2008; Midant-Reynes and Briois 2009; Briois and Midant-Reynes 2010), and resulted in the identification of many sites dating to the Holocene (Figure 2). In most cases, archaeological remains were found directly upon the surface. In other cases, stratified anthropogenic deposits were exposed by deflation. In some cases, there are substantial concentrations of artifacts and even hearths extending over large areas. These sites are frequently found associated with ancient artesian spring mounds.

\section{SOUTH KHARGA SITE KS043}

The KS043 site was excavated between 2002 and 2008. It is located $12 \mathrm{~km}$ southwest of Dush on a sand plain (Figure 1). It was identified as a group of ancient artesian springs surrounded by concentrations of chipped stone industry, pottery sherds, and faunal remains. The largest of these mounds

\footnotetext{
${ }^{1}$ Laboratoire de datation, Institut français d'archéologie orientale (IFAO), 37 al-sheikh Aly Yusef st., Cairo, Egypt. Corresponding author. Email: mwuttmann@ifao.egnet.net.

${ }^{2}$ Ecole des Hautes Etudes en Sciences Sociales (EHESS) and CNRS (UMR 5608 - TRACES), 5 allée Antonio Machado, 31058 Toulouse, France.

${ }^{3}$ Institut français d'archéologie orientale, 37 al-sheikh Aly Yusef st., Cairo, Egypt.

${ }^{4}$ Université de Toulouse and CNRS (UMR 5608 - TRACES), 5 allée Antonio Machado, 31058 Toulouse, France.
}

(C) 2012 by the Arizona Board of Regents on behalf of the University of Arizona Proceedings of the 6th International Radiocarbon and Archaeology Symposium, edited by E Boaretto and N R Rebollo Franco RADIOCARBON, Vol 54, Nr 3-4, 2012, p 305-318 


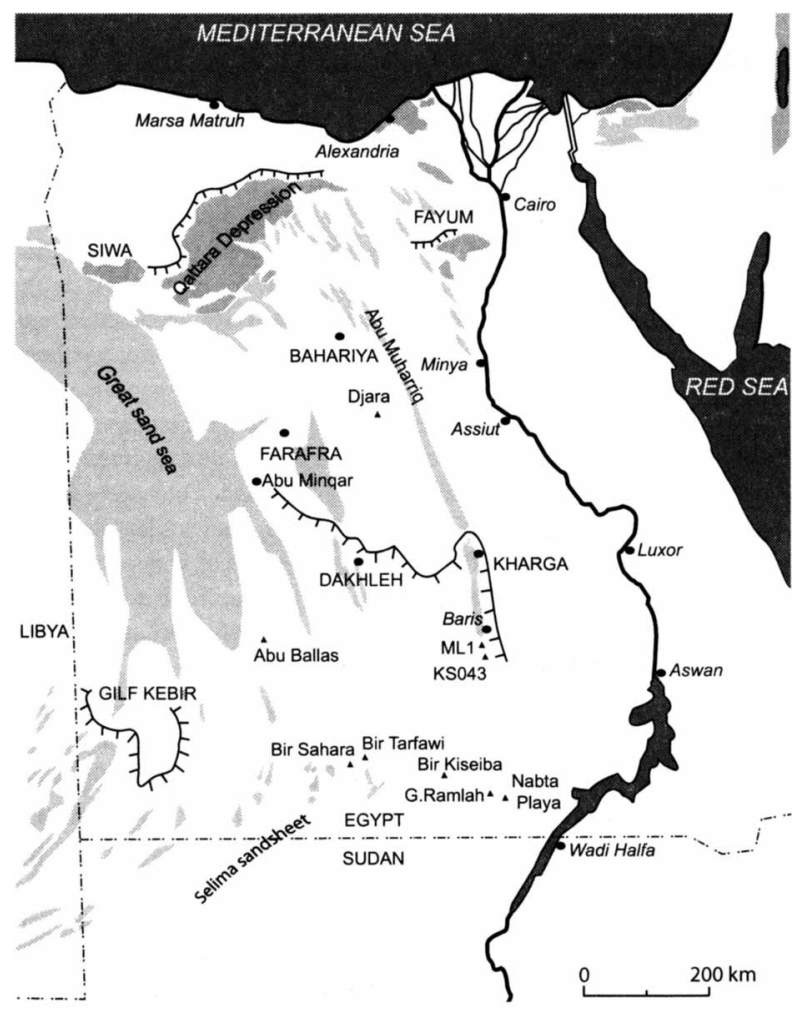

Figure 1 Location of main sites mentioned in the text

reaches a height of $1 \mathrm{~m}$ above the sandy plain for $75 \mathrm{~m}$ in diameter. Initially thought to be a surface scatter like most of the prehistoric sites in the eastern Sahara, it was instead revealed to be a stratified occupation with numerous settlement structures. The thick stratigraphic sequence $(1.3 \mathrm{~m})$ results from the accumulation of intermingled sedimentary deposits created by the artesian springs with deposits from human occupation. Two stratigraphic profiles and trenches in 4 sectors were excavated, ensuring analysis of the archaeological features both stratigraphically and spatially (Figure 3).

The site's rich archaeology includes markers pointing to the Late and Final Neolithic as defined by Wendorf and Schild (2001) for the Nabta Playa area in southern Egypt. Side-blow-flake scrapers, bifacial arrowheads, and knives are present as well as Black Topped pottery, Rippled Ware, and decorated caliciform vessels known as Tulip Beakers. The presence of Black Topped ceramics and Tulip Beakers suggest a relation with the Tasian culture (Briois et al. 2012). This entity, still poorly known, was first identified in the Badari region of Middle Egypt (Brunton 1937), but its existence as a distinct "cultural phase" was strongly called into question (Baumgartel 1960). Research in the Eastern and Western deserts (Friedman and Hobbs 2002; Gatto 2002, 2006) has proven the Tasian to be earlier and culturally distinct from the Badarian, and recent discoveries of Gebel Ramlah graveyards confirm this statement (Kobusiewicz et al. 2010). These 3 Western Desert cemeteries provide ${ }^{14} \mathrm{C}$ dates between 4700 and $4500 \mathrm{cal} \mathrm{BC}$ on charcoal. Artifacts found in these graves, including Black Topped vessels and Tulip Beakers, attest to the existence, $250 \mathrm{~km}$ west of the Nile Valley, of Tasian groups, some 300 to $500 \mathrm{yr}$ before the oldest Tasian-related site known in the Nile Valley, from 4200 to 3900 cal BC (Hendrickx et al. 2001). Research at site KS043 suggests this desert occupation is Neolithic and helps address the question of the origins of predynastic Egyptian cultures. 


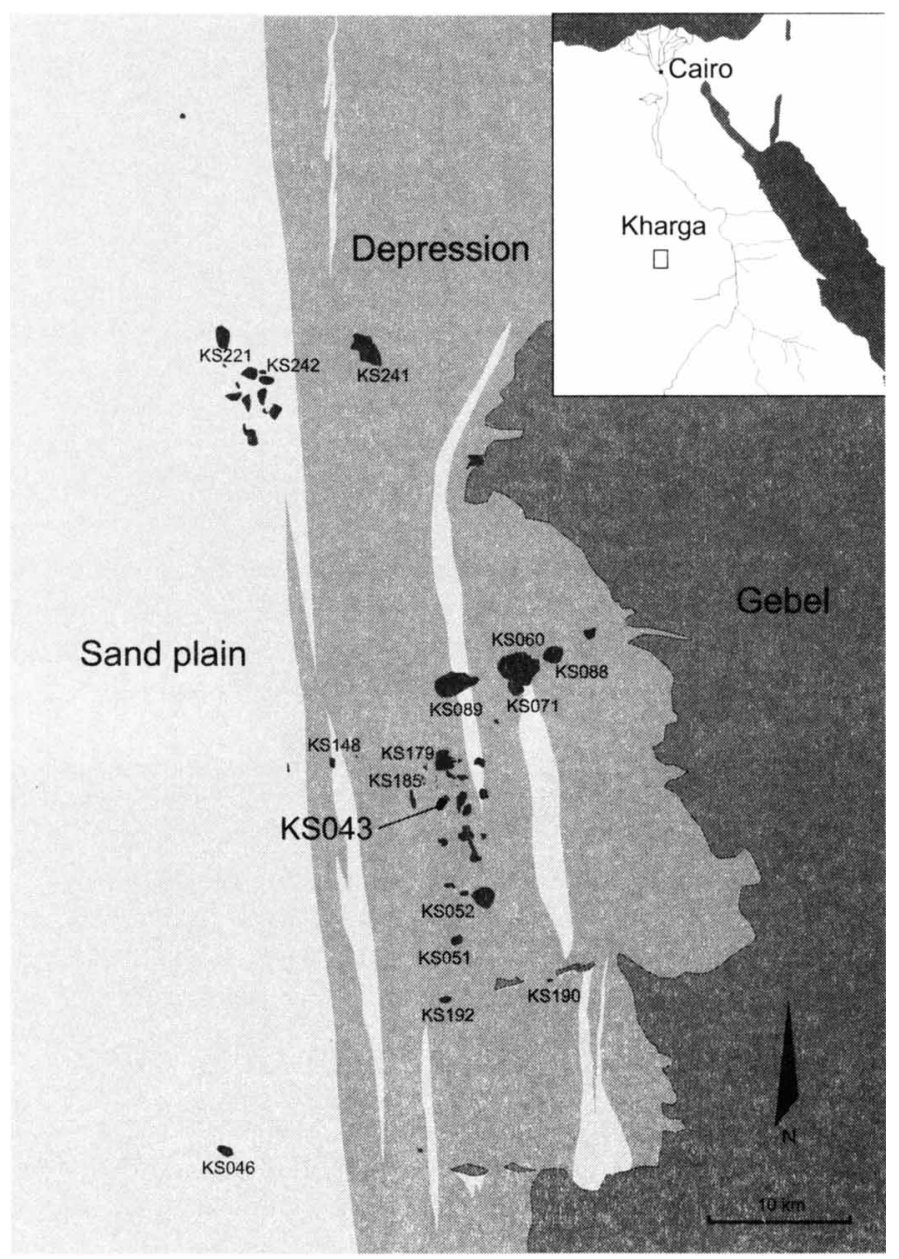

Figure 2 Southern Kharga Basin with location of sites KS043 and KS052

Most Egyptian prehistoric sites situated in arid environments have been exposed to extreme wind erosion and only subsist as surface scatter of artifacts. As a result of the nearby artesian activity, KS043 presents the exceptionally rare case in this environment of being a stratified site containing well-preserved organic materials. Anthropogenic traces found in the stratigraphy are interspersed with various natural deposits consisting of clay and eolian sands (Figure 4). These sedimentary accumulations have 2 types of origin: clays from the muddy effusions caused by intermittent artesian spring activity while the sandy deposits correspond to levels of accumulation produced by the wind on wet ground (Figure 5). These levels correspond to groups of small basins lined with clay, to many fireplaces, and to scattering of remains (fauna, ceramic, and stone industry) that were originally located around small natural ponds intermittently filled with water. The hearths have the aspect of bowl-shaped firepits filled with ashy concretions and well-preserved charcoal, sometimes associated with accumulations of heating stones (Figure 6a). A small stove containing ashes, charcoals, and fragments of shells of a cooked ostrich egg (St 14b) was also observed (Figure 6b). The best conditions were met to determine the chronological range of human occupation at KS043 and to assign cultural attribution by absolute dating. 


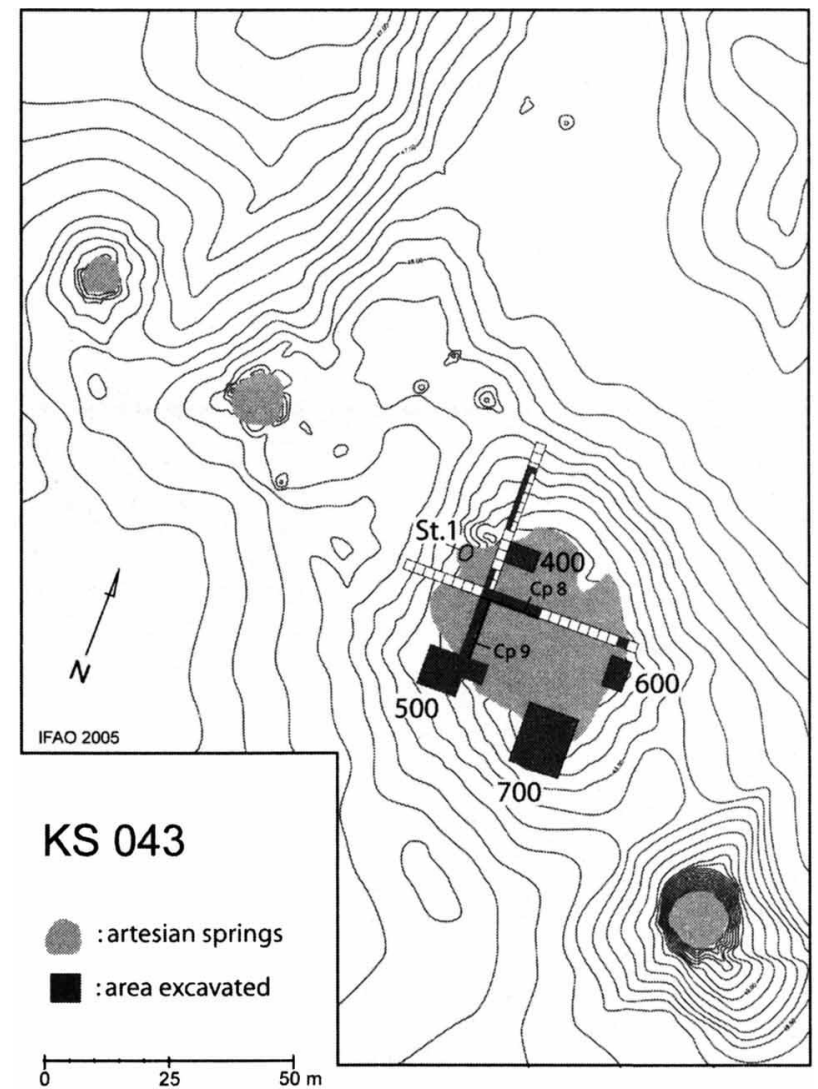

Figure 3 KS043 site map

\section{4}

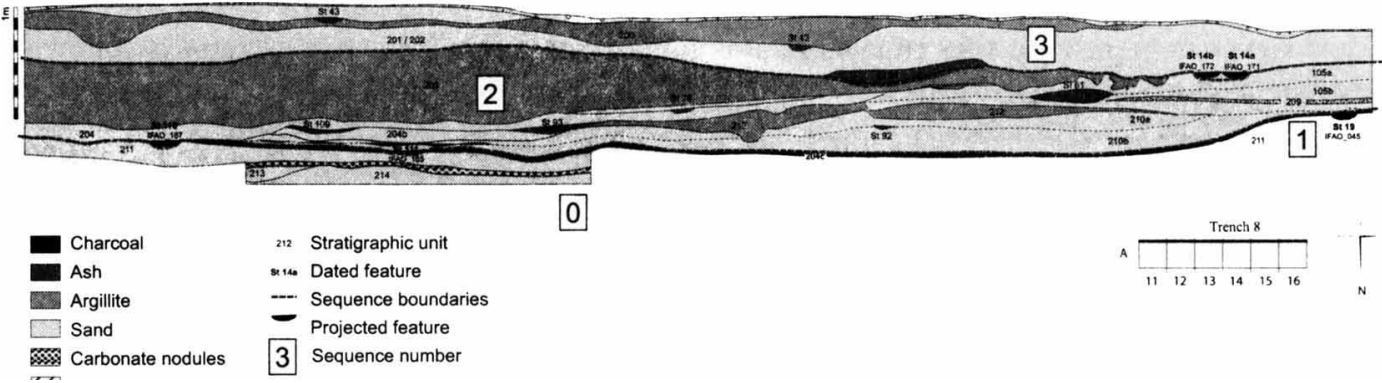

Figure 4 Site KS043: stratigraphic section with sequences established through ${ }^{14} \mathrm{C}$-dated hearths

It was thus possible to establish a phasing within this period of occupation. Furthermore, the close connection of several fireplaces with the ostrich egg remains also offered an opportunity to compare the results of radiometric measurements from charcoal and ostrich eggshells. 


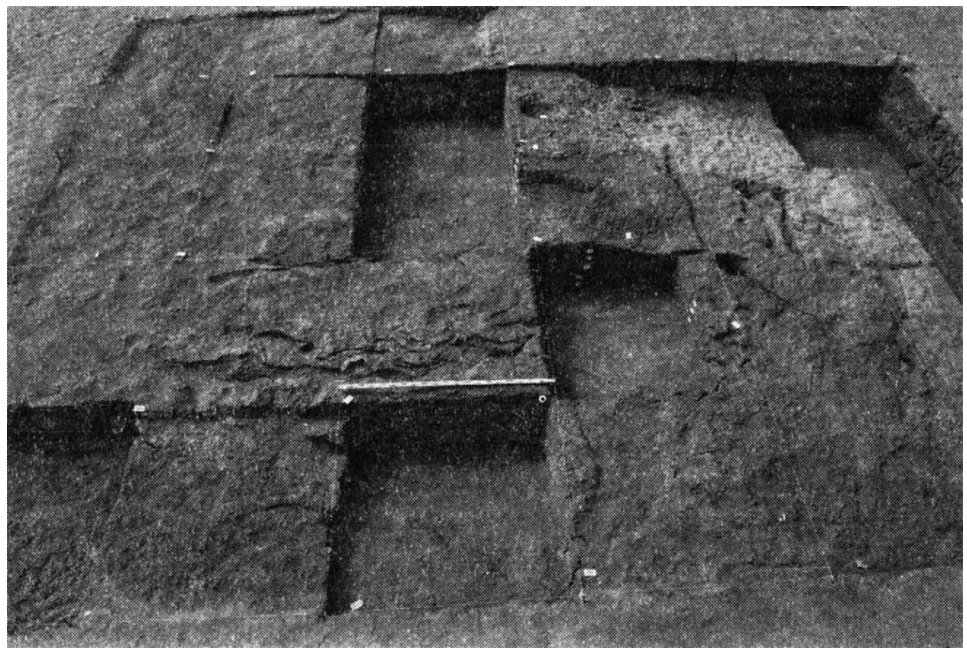

Figure 5 Site KS043: planimetric and stratigraphic excavation of sector 700
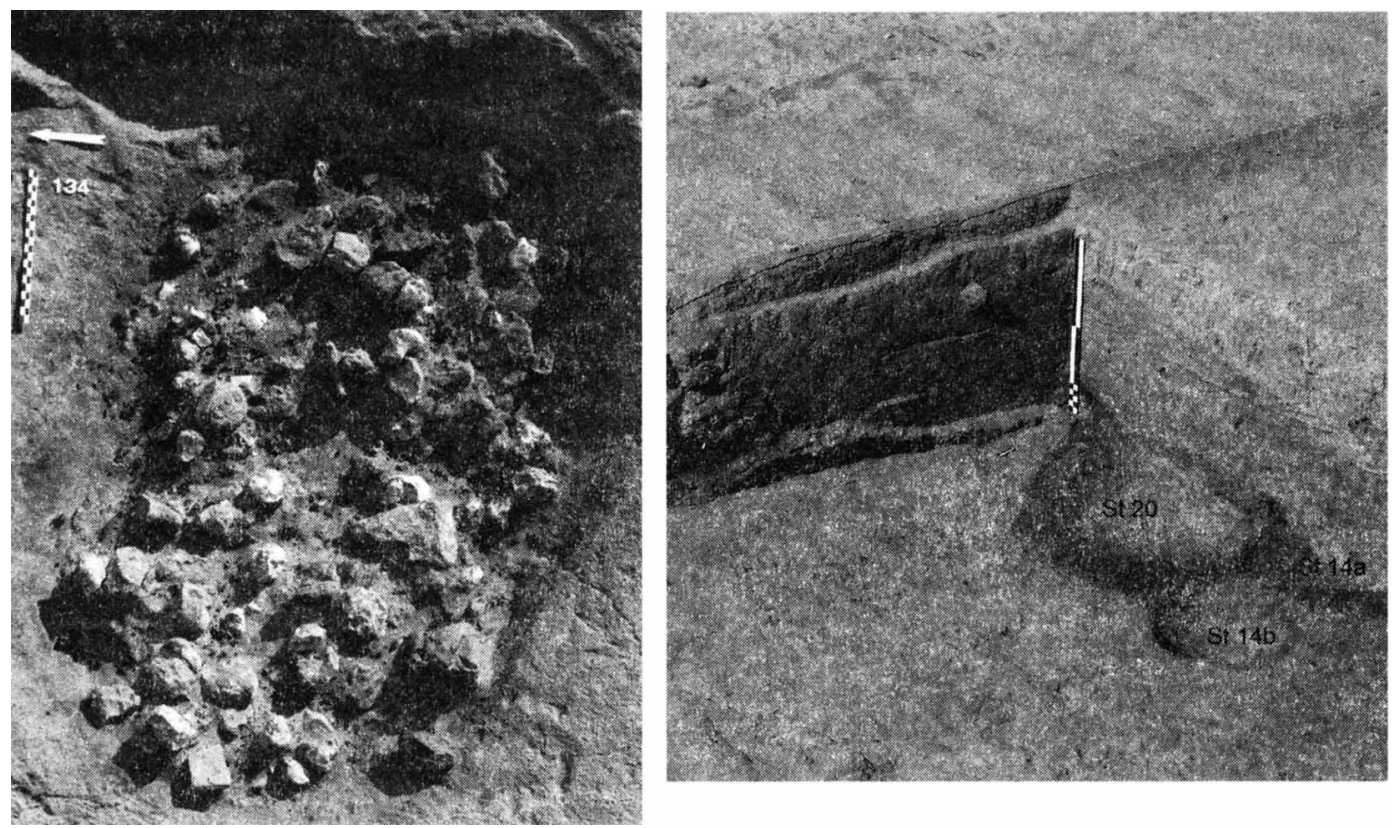

Figure 6 a) Hearth St 134; b) Hearth St 14

\section{THE ABSOLUTE CHRONOLOGY FOR SITE KS043}

\section{The Samples and Their Treatment}

Different organic materials were available for dating the activity of artesian springs and the human presence on the site: carbonate concretions and nodules, charcoals, fireplace ash fill, and fragments of ostrich eggshells. Sample selection was undertaken according to stratigraphic and spatial localization in order to cover the widest chronological range. The best-preserved in situ hearths containing a large amount of charcoal or ashy sediment in ensured layers were favored. On 2 occasions, the 
exceptional opportunity was available to crosscheck feature ages by dating both charcoal and ostrich eggshell within the same context. This was the case for the well-preserved small pit St 14b interpreted as a small stove made of an ostrich eggshell warmed by charcoal (Figure $6 \mathrm{~b}$ ). The same association was found in hearth St 111 situated at the base of the stratigraphy.

The liquid scintillation counting (LSC) equipment available in the Laboratoire de Datation at IFAO limited opportunities to sample to the few contexts that could provide the amount of material required by the LSC method. Therefore, 8 samples of charcoal, 1 fireplace ash fill, 3 samples of carbonate nodules and concretions, and 2 samples of ostrich eggshells were selected. In the laboratory, the charcoals were treated according to usual acid-base-acid (ABA) protocol: hydrochloric acid/ sodium hydroxyde/hydrochloric acid. The first acid treatment generated a strong reaction with microparticles of carbonates impregnating the samples. The alkaline treatment with $0.5 \mathrm{~N} \mathrm{NaOH}$ was stopped early because it was dissolving a large fraction of the samples. We observed this phenomenon on most charcoal samples collected on Neolithic sites in the southern part of the oasis of Kharga. Haas and Hayes (1980) have made similar findings and noted: "It can be concluded that incomplete removal of humate contamination from the charcoals is not a serious problem. This fact is not surprising since the Western Desert has not recently been covered by vegetation." We can reasonably make that assumption for site KS043, which is located about $500 \mathrm{~m}$ away from the closest cultivated areas, active for less than 2 centuries during Roman times. Ashy sediment has undergone the same ABA treatment. The surfaces of ostrich eggshell fragments were milled and then cleaned ultrasonically for $2 \mathrm{hr}$ in deionized water. The first fraction of $\mathrm{CO}_{2}$ generated by the acid attack of these fragments was eliminated. Sandy and clayey particles loosely adhering to carbonate concretions and nodules were removed by washing with deionized water. The first fraction of $\mathrm{CO}_{2}$ generated by the acid attack of these fragments was also eliminated. The ${ }^{14} \mathrm{C}$ activity of the benzene synthesized from the samples was measured on 2 PerkinElmer Tri-Carb ${ }^{\circledR} 3100$ counters.

\section{Modeling}

The distribution of datable samples and the stratigraphic data provided by excavation of the settlement were treated by a simple Bayesian model (Bronk Ramsey 2009a) consisting of 4 sequences (Figure 4) corresponding to the horizons with the main feature concentrations (Figures 5 and 6a,b):

Sequence 1: ${ }^{14} \mathrm{C}$ dates IFAO-045 (Feature St 19) and IFAO-168 (Feature St 134);

Sequence 2: ${ }^{14} \mathrm{C}$ dates IFAO-165 (Features St 111), -167 (Feature St 118), and -186 (Feature St 112);

Sequence $3:{ }^{14} \mathrm{C}$ dates IFAO-171 and IFAO-172 (Feature St 14a and St 14b);

Sequence 4: ${ }^{14} \mathrm{C}$ dates IFAO-266 (Feature St 141).

The carbonate nodules of the substrate, prior to human activity, were defined as a sequence 0 (IFAO271 and $-272{ }^{14} \mathrm{C}$ dates). Carbonate concretions formed around the roots of grasses and plants that have grown on the mound of the artesian spring in the east of the settlement were not included in this stratigraphic model.

A first calculation of the model showed that the 2 dates on ostrich eggshell, IFAO-082 and -170, were clear outliers: within feature St 111-ostrich eggshell date IFAO-170 (4594 \pm 72 BP) compared to charcoal date IFAO-165 (5840 $\pm 61 \mathrm{BP})$; within feature St 14b-ostrich eggshell date IFAO-082 (5109 \pm 69 BP) compared to charcoal date IFAO-172 (5699 \pm 51 BP). They have therefore been excluded from the final model presented here. This discrepancy between charcoal and ostrich eggshell dates will be discussed below. An Outlier model (Bronk Ramsey 2009b) has been used for the charcoal samples to take into account any old-wood effects. 


\section{RESULTS: THE ABSOLUTE CHRONOLOGY OF SITE KS043}

Calculation of the model based on the available data provides good results (Figure 7). The model would certainly have been better had we not been constrained by the requirements of the LSC technique, the only available technique in Egypt. Indeed, the excavations yielded other hearths that unfortunately did not preserve sufficient quantities of charcoal to be used to refine the Bayesian model and thus allow a more precise evaluation of the time intervals between the major phases of anthropic activity on the site. One of the posterior probability distributions (IFAO-186) is nevertheless near to the threshold $(60 \%)$ of the agreement index as calculated by the OxCal software.

Our proposal for the absolute chronology of the site can be summarized as follows:

- Sequence 0: artesian activity during the Pleistocene is represented by the carbonate nodules found in the sandy clay substrate. The ${ }^{14} \mathrm{C}$ dates measured on 2 samples range from 31,000 28,000 BP (Table 1; Figure 7). This range is considered with great caution, since we do not know the mechanism of carbon exchanges that led to the formation of the nodules. We cannot, in particular, assess what fraction of fossil carbon dissolved in the soil was involved.

- Sequence 1: fires, before $5000 \mathrm{cal}$ BC. The hearth St 19 was embedded in the hard mantel of the artesian spring; hence, the ancient age obtained may result from an Epipaleolithic occupation preceding the main sequence. Hearth St 134 is by contrast well inserted in the sedimentary dynamic and gave a result closer to the rest of the determinations. It led us to retain it as the most ancient date for Neolithic occupation.

- Sequences 2, 3, and 4: numerous structures reflecting regular occupation of the site. The stratigraphic distribution of the samples allows us to assess the dates of a few key stratigraphic units (Figure 8):

US204c to $210 \mathrm{~b}$ (sequence 2): $4450-4330 \mathrm{cal} \mathrm{BC}(95.4 \%)$;

US201 to 202 (sequence 3): $4417-4161$ cal BC (95.4\%);

US703 (sequence 4): 4228-3964 cal BC (95.4\%).

The site was then abandoned, probably for lack of water, as evidenced by the attempts at digging in the artesian spring next to the settlement. In conclusion, the main occupation pertaining to the Neolithic range from 5000 to $3950 \mathrm{cal} \mathrm{BC}$ was concentrated in sequences 2 and 3: $4600-4350 \mathrm{cal}$ BC.

The younger ostrich eggshell dates need explanation. As we have taken into account isotopic fractionation in age calculation, we had to investigate postburial physico-chemical interactions with the environment of ostrich eggshell fragments as dissolution and redeposition of carbonates should be suspected in active artesian areas. However, the preliminary studies performed on the fragments used for dating at site KS043 did not reveal any redeposition structures under SEM examination (Figure 9). Further laboratory investigations are still needed.

\section{Discrepancies between Charcoal and Ostrich Eggshell Dates}

The suitability of ostrich eggshell for ${ }^{14} \mathrm{C}$ determinations has been previously studied (e.g. Haas and Haynes 1980; Freundlich et al. 1989; Vogel et al. 2001). It is considered a reliable material if corrected for isotope fractionation with the aid of the $\delta^{13} \mathrm{C}$ content vs. PDB using the 25\%o standard (Stuiver and Polach 1977; Freundlich et al. 1989). Only Vogel et al. (2001) signal that the carbonate fraction of the shell may display an initial deficit in ${ }^{14} \mathrm{C}$, which causes the ages to appear $180 \pm 120$ yr too old. 


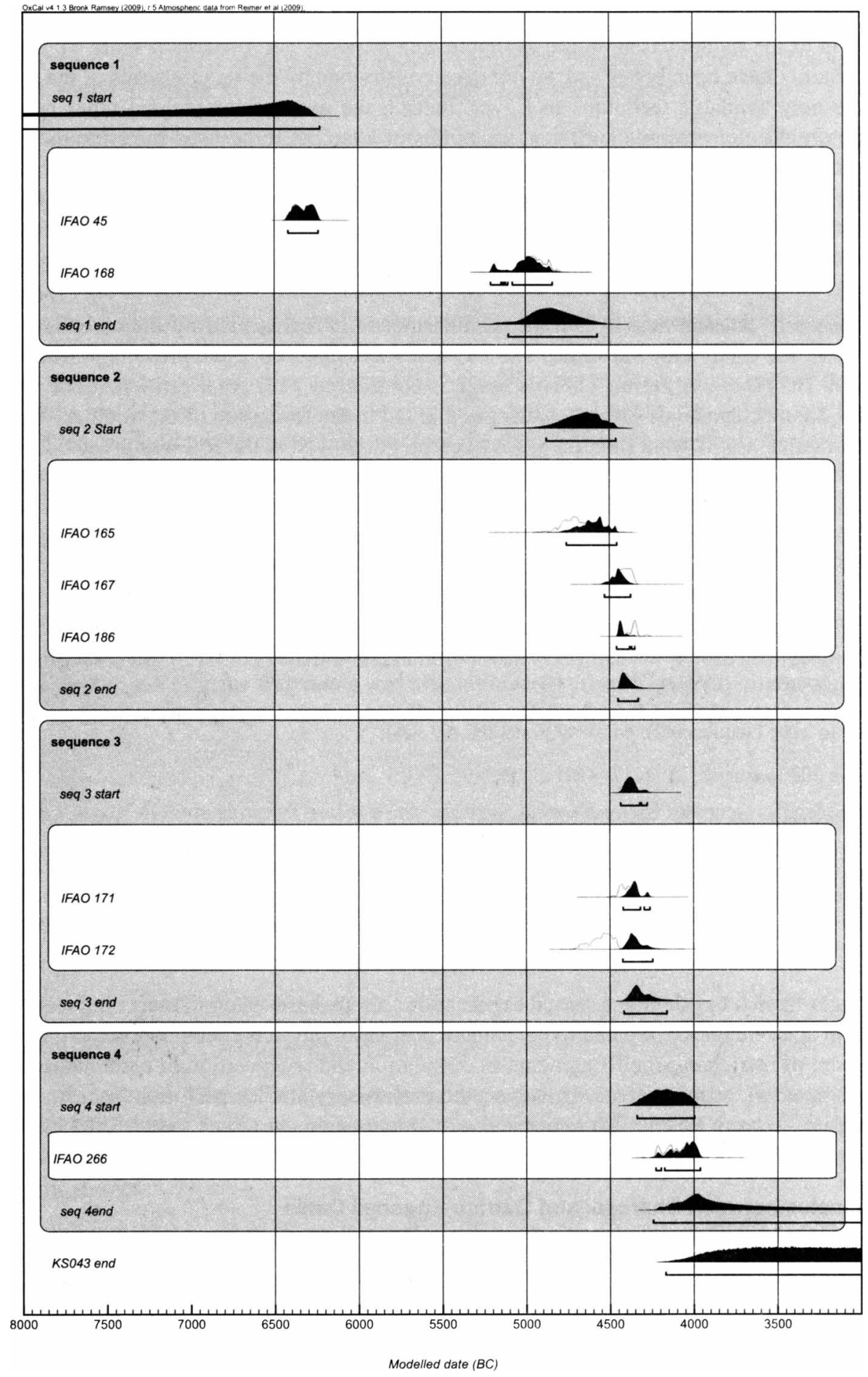

Figure 7 Output of the OxCal v 4.1.3 calculations of the Bayesian model for the site KS043 chronology 
Table 1 Sample description and individual measurement results.

\begin{tabular}{lllc}
\hline Sample nr & Description & Context & $\begin{array}{l}\text { Age (yr BP) } \\
(1 \sigma)\end{array}$ \\
\hline IFAO-272 & Carbonated nodules & Bedrock & $28,693 \pm 326$ \\
IFAO-271 & Carbonated nodules & Bedrock & $30,897 \pm 380$ \\
IFAO-045 & Small charcoals & Hearth St 19 & $7460 \pm 83$ \\
IFAO-168 & Small charcoals & Hearth St 134 & $6053 \pm 52$ \\
IFAO-165 & Small charcoals & Hearth St 111 & $5840 \pm 61$ \\
IFAO-167 & Small charcoals & Hearth St 118 & $5586 \pm 50$ \\
IFAO-186 & Ashy sediment and small charcoals & Hearth St 112 & $5512 \pm 34$ \\
IFAO-171 & Small charcoals & Hearth St 14a & $5530 \pm 50$ \\
IFAO-172 & Small charcoals & Hearth St 14b & $5699 \pm 51$ \\
IFAO-266 & Small charcoals & Hearth St 141 & $5248 \pm 51$ \\
IFAO-082 & Ostrich eggshell & Hearth St 14b & $5109 \pm 69$ \\
IFAO-170 & Ostrich eggshell & Hearth St 111 & $4594 \pm 72$ \\
IFAO-273 & Carbonated nodules & Rootcasts on artesian spring mound & $5967 \pm 52$ \\
\hline
\end{tabular}

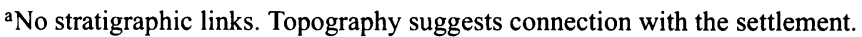
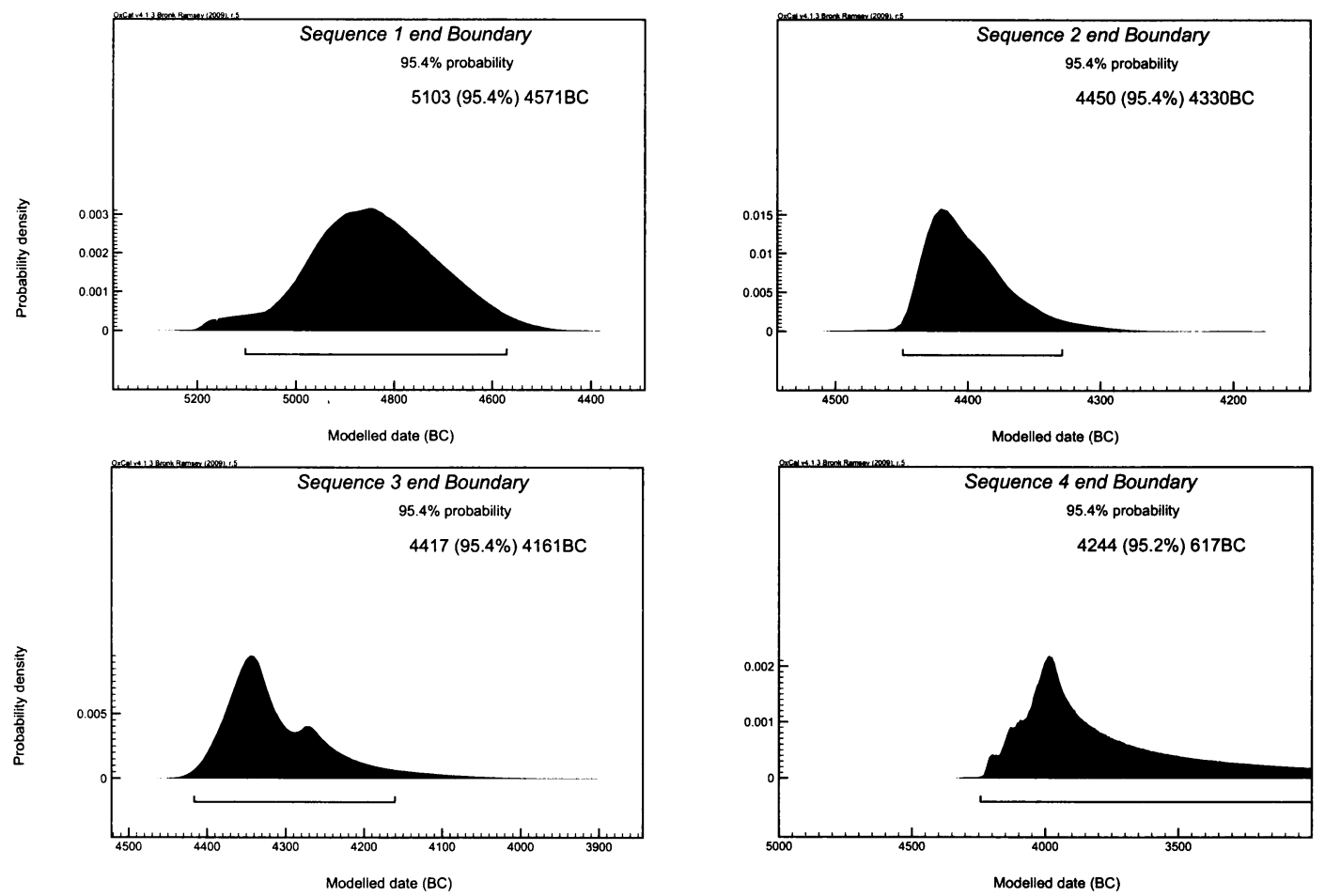

Figure 8 Probability distributions for the modeled dates of the end boundaries of the 4 main sequences

At site KS043, considerable discrepancies between ostrich eggshell and charcoal samples were noted in very well-preserved in situ contexts. The ostrich eggshell samples gave noticeably younger dates (1200 and $600 \mathrm{yr}$, respectively) compared to the associated charcoals. The Bayesian model elaborated for KS043 conducted us to discard those 2 results. This particular situation highlights the need to question again the suitability of this material for ${ }^{14} \mathrm{C}$ dating. 


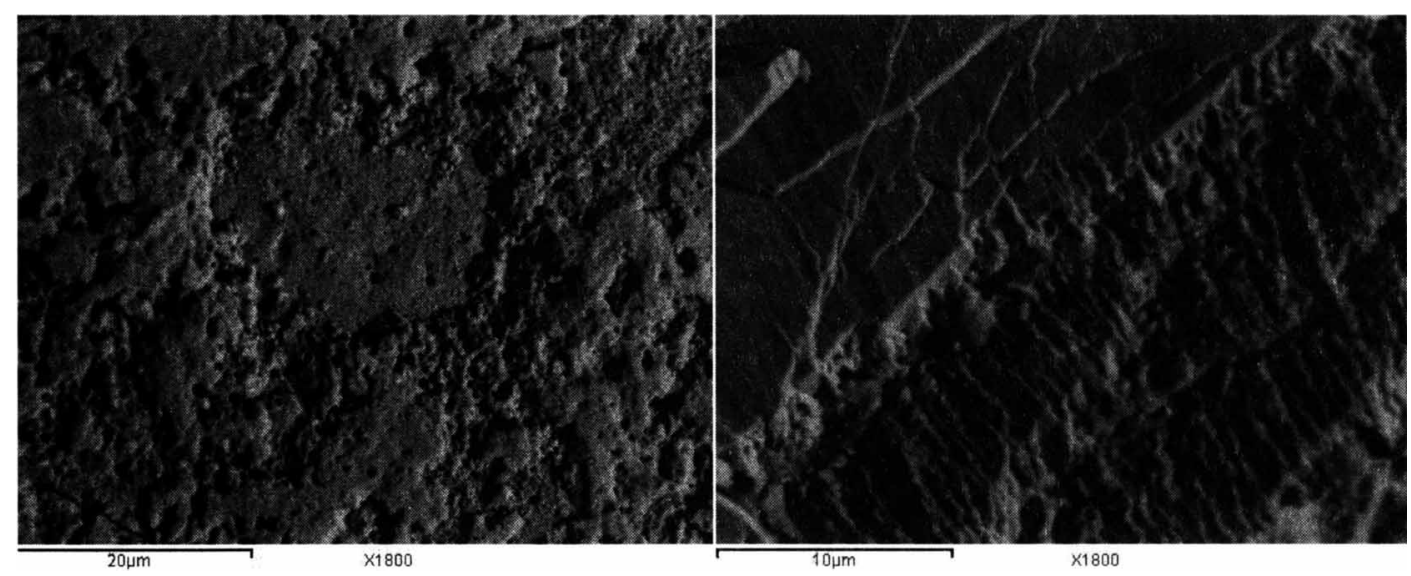

Figure 9 Outer surface and cross-section of ostrich eggshell fragment (IFAO-045). Under SEM examination, we can identify dissolution of the outer surface (left), without secondary redeposition.

Due to the poor preservation of charcoal, wood, and bones in desert environments, ostrich eggshell has been widely used for ${ }^{14} \mathrm{C}$ determinations in the study of Holocene prehistory in the eastern Sahara. This material has contributed to build large-scale reconstructions of climate and human occupation (e.g. Kuper and Kröpelin 2006) and regional chronological sequences. Among $686{ }^{14} \mathrm{C}$ determinations ascribable for the western desert of Egypt and oases for Holocene prehistory, 132 were identified as being ostrich eggshell samples (Table 2).

Table 2 Review of eastern Sahara ${ }^{14} \mathrm{C}$ dates on charcoal and ostrich eggshell.

\begin{tabular}{|c|c|c|c|c|c|c|}
\hline \multirow[b]{2}{*}{ Region } & \multirow[b]{2}{*}{${ }^{14} \mathrm{C}$ dates } & \multicolumn{2}{|c|}{ OES dates } & \multicolumn{2}{|c|}{ OES discarded } & \multirow[b]{2}{*}{ References $^{\mathrm{a}}$} \\
\hline & & $n$ & $\%$ & $n$ & $\%$ & \\
\hline Abu Ballas & 88 & 2 & $2 \%$ & 0 & $0 \%$ & $1,2,3,4$ \\
\hline Abu Muhariq & 60 & 8 & $13 \%$ & 4 & $50 \%$ & $5,4,6$ \\
\hline Baharia & 3 & 3 & $100 \%$ & 0 & $0 \%$ & 7,8 \\
\hline Nabta-Kiseiba & 200 & 16 & $8 \%$ & 8 & $50 \%$ & $9,10,11,2,12,13,14$ \\
\hline Dahkleh & 87 & 46 & $53 \%$ & 9 & $20 \%$ & $15,16,17,18,13$ \\
\hline Farafra & 21 & 6 & $29 \%$ & 0 & $0 \%$ & $19,20,7$ \\
\hline Gilf Kebir & 57 & 6 & $11 \%$ & 0 & $0 \%$ & $7,1,21,4,22$ \\
\hline Great Sand See & 71 & 13 & $18 \%$ & 0 & $0 \%$ & $1,21,4,23$ \\
\hline Kharga & 33 & 15 & $45 \%$ & 2 & $13 \%$ & $24,10,25,26,14$ \\
\hline Selima Sandsheet & 18 & 4 & $22 \%$ & 0 & $0 \%$ & $1,27,21,4$ \\
\hline Siwa & 48 & 13 & $27 \%$ & 1 & $8 \%$ & $28,29,1,30,31,32,4$ \\
\hline Total & 686 & 132 & $19 \%$ & 24 & $18 \%$ & \\
\hline
\end{tabular}

a 1. Freundlich et al. 1989; 2. Hendrickx 1999; 3. Kuper 1993; 4. Kuper and Kröpelin 2006; 5. Kindermann 2010; 6. Riemer et al. 2004; 7. Close 1984; 8. Hassan 1979; 9. Close 1980; 10. Haas and Haynes 1980; 11. Hedges et al. 1994; 12. Kobusiewicz et al. 2009; 13. Pazdur et al. 1994; 14. Wendorf and Schild 2001; 15. Brookes 1989; 16. McDonald 1990; 17. McDonald 2001; 18. McDonald 2003; 19. Alessio et al. 1992; 20. Barich and Hassan 2000; 21. Kuper 1989; 22. Schön 1996; 23. Riemer 2000; 24. Briois et al. 2008; 25. Holmes 1991; 26. McDonald 2009; 27. Hahn 1993; 28. Close 1980; 29. Cziesla 1993; 30. Hassan 1976; 31. Hassan 1978; 32. Hassan and Gross 1987.

Through a literature review in relation to prehistoric Egypt, we compared dates obtained from ostrich eggshell with samples from other organic materials and typochronological analyses in order to detect if in any case ostrich eggshell has given inconsistent results comparable to those identified at $\mathrm{KS} 043$. 
Diverse methods of correction for isotope fractionation have been in use through time. Most ancient dates on ostrich eggshell were not corrected or do not specify if a correction for isotope fractionation has been applied. Certain dates are corrected for fractionation to a standard of $-6.2 \%$ (Close 1980 , $1984,1988)$. Regarding dates where $\delta^{13} \mathrm{C}$ has not been measured, some authors add a constant factor of $350 \mathrm{yr}$ (McDonald 2001) based on the average result of recalculation of a series of dates to a 25\% standard (Wendorf et al. 1984:409), while others give the raw dates instead of estimated values (Wendorf and Schild 2001). This confusing picture raises the question of the coherence of available data for global synthesis. We based our study on the most recent information available, assuming that dates on ostrich eggshell are coherent within given studies. We discarded the dates unequivocally rejected by authors and previously published determinations that have not been included by authors of the recent regional synthesis, whether or not the reason is explicit. It is worth noting that the global rate of discarded data reaches $18 \%$ for this material in the reviewed literature.

The Combined Prehistoric Expedition established a sequence for the Holocene occupation of the Western Desert based on $185{ }^{14} \mathrm{C}$ dates from Nabta Playa, Bir Kiseiba, and Kharga (Wendorf and Schild 2001). Of these, 12 are on ostrich eggshell and 4 of these have been discarded for conflicting with the typochronology. The most ancient phase, El Adam, has been dated using charcoal only. The dating of the El Ghorab period relies on ostrich eggshell for 5 out of 7 determinations, with all dates grouped at the end of the 9th millennium BP. For Al Jerar, the only sample of this material is totally coherent with the other data from site E-77-1 from which it derives and for other sites of the same typochronological attribution. For the Final Neolithic, a single date on ostrich eggshell comes from a site (BT20) and constitutes the sole dating but is consistent with the limits proposed for the phase.

On the Abu Muhariq Plateau at Djara (Kindermann 2010), 4 out of 5 dates performed on ostrich eggshell were discarded as being incoherent with the typochronology: being 300 to $900 \mathrm{yr}$ too old and another one being $300 \mathrm{yr}$ too recent.

The Dahkleh sequence (McDonald 2001, 2003) strongly relies on ostrich eggshell $\left(53 \%\right.$ of ${ }^{14} \mathrm{C}$ dates). Among the 6 determinations used to define the chronological range of the Masara A cultural unit, 4 are on ostrich eggshell and give dates 500 to $1300 \mathrm{yr}$ older than charcoal samples, even on the same locality (site 166), without having been discarded (McDonald 2003). Masara B is only dated on 2 ostrich eggshell samples. Consequently, no comparison is possible. For Masara C, 2 out of 10 dates have been performed on ostrich eggshell; they fit well in this series restricted to the first half of the 9th millennium BP. The same is seen for Bashendi A and B but those periods spans respectively 2 millennia, which makes it difficult to detect potential divergences. Site 254 for example is occupied from $6300 \pm 110$ to $5180 \pm 110 \mathrm{BP}$, without specific description of the context of the samples, nothing can be said about the precision of ostrich eggshell determinations. Two out of the 4 determinations on ostrich eggshell for the late Holocene cultural unit Sheikh Muftah have been discarded for giving an Epipaleolithic age probably pertaining to older occupations. It must be signaled that AMS checks have been performed on the organic residue of charred samples of ostrich eggshell from Dahkleh previously dated by the conventional ${ }^{14} \mathrm{C}$ method (Brookes 1989:145, 150). AMS dates have been discarded by the authors for giving unexplained incoherent results.

At Kharga, the Epipaleolithic site ML1 at Ayn Manawir (Briois et al. 2008) has been dated solely by ostrich eggshell. The lithic analysis shows that it is similar to the El-Ghorab entity identified in the Nabta-Kiseiba area. However, there is a gap of nearly $1000 \mathrm{yr}$ between the period proposed for El Ghorab and the MLl occupation. As charcoal was not available in sufficient quantity for ${ }^{14} \mathrm{C}$ dating, it is impossible to assess whether those results signal a regional development of this material culture or a particular problem with ostrich eggshell samples at ML1. It is worth mentioning that this surface site is also situated in an artesian environment. 
All the dates obtained on ostrich eggshell from Abu Ballas, Baharia, Farafra, Gilf Kebir, Great Sand Sea, and Selima sandsheet area in Egypt are accepted in their publications and in comparisons with existing information. Based on the data available, it seems that the ostrich eggshell determinations fit pretty well into regional and site sequences. However, ostrich eggshell dates seem slightly more prone to be discarded than other material, and the variation to expected results is unpredictable. Incoherent ages are mostly attributed to discrete occupations pertaining to a different age than the one identified in the archaeological remains. The archaeological context of the sample origin is often reduced to a global site provenience in publications and insufficiently described to identify possible mismatches. Cultural units of the eastern Sahara are still roughly defined and span wide ranges of time; the duration of occupation of the archaeological sites is frequently important. Consequently, identifying a discrepancy of a few centuries is a complicated task. Due to the lack of other material available for ${ }^{14} \mathrm{C}$ measurement, small and surface sites rely frequently only on ostrich eggshell as a sole material for dating, at times on a single sample. In those cases, it is impossible to compare to other absolute dates and we have to rely on the somewhat loose cultural sequences. The frequent palimpsests in the desert environment where sedimentation is low are another bias that makes it difficult to detect incoherencies. Such a favorable in situ context for comparison as the one we studied at KS043 has not been discussed before for the concerned area. One of the tracks we are following is to identify the origin of the discrepancies is the interaction between carbonates from the artesian spring and ostrich eggshell. During the progressive drying of the eastern Sahara, people retreated toward water sources. Many of those favorable places are situated in oases around artesian springs. Consequently, one cannot rule out that the problem faced at KS043 with ostrich eggshell took place elsewhere with no possibility to detect it.

\section{DISCUSSION AND CONCLUSION}

This modeling of absolute chronology for site KS043 permitted to build a firm chronological sequence for one of the few well-stratified Holocene sites excavated in the eastern Sahara. Better knowledge of the absolute chronology of this devolution requires a thorough review of available ${ }^{14} \mathrm{C}$ dates and their contexts of sampling. Recently developed strategies for dating outstanding sites should provide new benchmarks and chronological links. The measurements have also revealed inconsistent dates obtained on charcoal and ostrich eggshell. The results obtained at KS043 come from absolutely reliable contexts and, despite the low number of samples, they bring to the fore a matter nowhere else addressed. We do not claim that our preliminary results invalidate previous determinations obtained on ostrich eggshell. Nonetheless, they draw attention to possible problems in specific contexts and open the discussion on the different ways available to detect and resolve these questions. Thus, physico-chemical interactions (artesian water and hardwater effects) in local postdepositional burial environments should be investigated thoroughly.

Traces of Neolithic occupation currently acknowledged in the eastern Sahara are closely linked to the changing climatic conditions that prevailed in northeastern Africa during the Holocene period (Kuper 2006; Kuper and Kröpelin 2006). Landscapes experienced a progressive drying while frequented by populations of hunter-gatherers who gradually became pastoralists. The playa lakes disappeared and sites concentrated where water could be easily captured by wells. Humans found shelter in refuge areas like oases where artesian springs provided water, while most of the Sahara had become totally inhospitable. Several sites discovered in the southern basin of Kharga allow specifically to study the adaptive patterns of human groups at the end of the Neolithic in an area where many springs were still active. The dating results on charcoal for site KS043 fit well into the chronology and the material culture defined in this region as late Neolithic and related to the Tasian desert cultural complex (Friedman and Hobbs 2002). 


\section{REFERENCES}

Alessio M, Barich BE, Belluomini G, Hassan FA, Mahmoud AA, Manfra L, Stoppiello A. 1992. A further report on Farafra (Western Desert, Egypt): new research and radiocarbon dates. Nyame Akuma 38:19-28.

Barich B, Hassan FA. 1984-1987. The Farafra Oasis archaeological project (Western Desert, Egypt), 1987 field campaign. Origini 13:117-91.

Barich BE, Hassan FA. 2000. A stratified sequence from Wadi el-Obeyd, Farafra: new data on subsistence and chronology of the Egyptian Western Desert. In: Krzyzaniak L, Kroeper K, Kobusiewicz M, editors. Recent Research into the Stone Age of Northeastern Africa. Studies in African Archaeology. Poznań: Poznań Archaeological Museum. p 11-20.

Baumgartel E. 1960. The Cultures of Prehistoric Egypt. Volume II. Oxford: Ashmolean Museum.

Briois F, Midant-Reynes B. 2010. L'oasis de Kharga dans la Préhistoire: aux origines des cultures prédynastiques. Archéo-Nil 20:43-50.

Briois F, Midant-Reynes B, Wuttmann M. 2008. Le gisement épipaléolithique de ML1 à Ayn-Manâwir: oasis de Kharga. Cairo: Institut français d'archéologie orientale.

Briois F, Midant-Reynes B, Marchand S, Tristant Y, Wuttmann M, De Dapper M, Lesur J, Newton C. 2012. Neolithic occupation of an artesian spring: KS043 in the Kharga Oasis, Egypt. Journal of Field Archaeology 37(3): 178-91.

Bronk Ramsey C. 2009a. Bayesian analysis of radiocarbon dates. Radiocarbon 51(1):337-60.

Bronk Ramsey C. 2009b. Dealing with outliers and offsets in radiocarbon dating. Radiocarbon 51(3):102345.

Brookes IA. 1989. Early Holocene basinal sediments of the Dakhleh Oasis region, south central Egypt. Quaternary Research 32(2):139-52.

Brunton G. 1937. Mostagedda and the Tasian Culture. British Museum Expedition to Middle Egypt, 1928-9. London: British Museum Press.

Caton-Thompson G. 1952. Kharga Oasis in Prehistory. London: University of London.

Close AE. 1980. Current research and recent radiocarbon dates from northern Africa. The Journal of African History 21(2):145-67.

Close AE. 1984. Current research and recent radiocarbon dates from northern Africa II. The Journal of African History 25(2):1-24.

Cziesla E. 1993. Investigations into the archaeology of the Sitra-Hatiyet, northwestern Egypt. In: Krzyzaniak L, Kobusiewicz M, Alexander J, editors. Environmental Change and Human Culture in the Nile Basin and Northern Africa Until the Second Millennium BC. Poznań: Poznań Archaeological Museum. p 185-97.

Freundlich JC, Kuper R, Breunig P, Bertram H-G. 1989. Radiocarbon dating of ostrich eggshells. Radiocarbon 31(3):1030-4.
Friedman R, Hobbs J. 2002. A 'Tasian' tomb in Egypt's Eastern Desert. In: Friedman RF, editor. Egypt and Nubia. Gifts of the Desert. London: British Museum Press. p 178-91.

Gatto M. 2002. Ceramic traditions and cultural territories: the "Nubian Group" in prehistory. Sudan \& Nubia 6:8-19.

Gatto M. 2006. Prehistoric Nubian ceramic traditions: origin, development and spreading trajectories. In: Caneva I, Roccati A, editors. Proceedings of the 10th International Conference of Nubian Studies, Rome 914 September 2002. Rome. p 103-6.

Haas H, Haynes C. 1980. Discussion of radiocarbon dates from the Western Desert. In: Wendorf F, Schild R, editors. Prehistory of the Eastern Sahara. New York: Academic Press. p 373-8.

Hahn J. 1993. Neolithic settlement patterns in the Gebel Kamil area, southwestern Egypt. In: Krzyzaniak L, Kobusiewicz M, Alexander J, editors. Environmental Change and Human Culture in the Nile Basin and Northern Africa Until the Second Millennium BC. Poznań: Poznań Archaeological Museum. p 225-36.

Hassan FA. 1976. Prehistoric studies of the Siwa Oasis region, northwestern Egypt. Nyame Akuma 9:18-34.

Hassan FA. 1978. Archaeological explorations of the Siwa Oasis region, Egypt. Current Anthropology 19(1):146-8.

Hassan FA. 1979. Archaeological explorations at Baharia Oasis and the West Delta, Egypt. Current Anthropology 20(4):806.

Hassan FA, Gross GT. 1987. Resources and subsistence during the early Holocene at Siwa Oasis, northern Egypt. In: Close AE, editor. Prehistory of Arid North Africa: Essays in Honor of Fred Wendorf. Dallas: Southern Methodist University Press. p 85-103.

Haynes Jr CV, Eyles CH, Pavlish LA, Ritchie JC, Rybak M. 1989. Holocene palaeoecology of the eastern Sahara; Selima Oasis. Quaternary Science Reviews 8(2): 109-36.

Hedges REM, Housley RA, Bronk Ramsey C, van Klinken GJ. 1994. Radiocarbon dates from the Oxford AMS system: Archaeometry datelist 18. Archaeometry 36(2):337-74.

Hendrickx S. 1999. La chronologie de la préhistoire tardive et des débuts de l'histoire de l'Egypte. Archeo Nil 9:13-81.

Hendrickx S, Midant-Reynes B, Van Neer W. 2001. Mahgar Dendera 2 (Haute Egypte): un site d'occupation Badarien. Leuven: Leuven University Press.

Holmes DL. 1991. Analysis and comparison of some prehistoric projectile points from Egypt. Institute of $\mathrm{Ar}$ chaeology Bulletin 28:99-132.

Kindermann K. 2010. Djara. Zur mittelholozänen Besiedlungsgeschichte zwischen Niltal und Oasen (Abu Muharik-Plateau, Ägypten). Köln: Henrich Barth Institut. 
Kobusiewicz M, Kabaciski J, Schild R, Irish JD, Wendorf F. 2009. Burial practices of the Final Neolithic pastoralists at Gebel Ramlah, Western Desert of Egypt. British Museum Studies in Ancient Egypt and Sudan 13:147-74.

Kobusiewicz M, Kabaciski J, Schild R, Irish JD, Gatto MC, Wendorf F. 2010. Gebel Ramlah, Final Neolithic Cemeteries from the Western Desert of Egypt. Poznań: Poznań Archaeological Museum.

Kuper R. 1989. The eastern Sahara from north to south: data and dates from the BOS Project. In: Krzyzaniak L, Kobusiewicz M, editors. Late Prehistory of the Nile Basin and the Sahara. Poznań: Poznań Archaeological Museum. p 197-203.

Kuper R. 1993. Sahel in Egypt: environmental change and cultural development in the Abu Ballas area, Libyan Desert. In: Krzyzaniak L, Kobusiewicz M, Alexander J, editors. Environmental Change and Human Culture in the Nile Basin and Northern Africa Until the Second Millennium BC. Poznań: Poznań Archaeological Museum. p 213-24.

Kuper R. 2006. After 5000 BC: the Libyan Desert in transition. Comptes rendus de Palévol 5:409-19.

Kuper R, Kröpelin S. 2006. Climate-controlled Holocene occupation in the Sahara: motor of Africa's evolution. Science 313(5788):803-7.

McDonald MMA. 1990. New evidence from the Early to Mid-Holocene in Dakhleh Oasis, south-central Egypt, bearing on the evolution of cattle pastoralism. Nyame Akuma 33:3-8.

McDonald MMA. 1999. Neolithic cultural units and adaptations in the Dakhleh Oasis. In: Churcher CS, Mills AJ, editors. Reports from the Survey of the Dakhleh Oasis 1977-1987. Oxford: Dakhleh Oasis Project Monograph 2. p 117-32.

McDonald MMA. 2001. The late prehistoric radiocarbon chronology for Dakhleh Oasis within the wider environmental and cultural setting of the Egyptian Western Desert. In: Marlow M, editor. The Oasis Paper 1: Proceedings of the First Dakhleh Oasis Project Seminar. Oxford: Dakhleh Oasis Project: Monograph 6. p 2641.

McDonald MMA. 2003. The early Holocene Masara A and Masara $C$ cultural sub-units of Dakhleh Oasis, within a wider cultural setting. In: Bowen GE, Hope CA, editors. The Oasis Papers 3. Proceedings of the Third Conference of the Dakhleh Oasis Project. Oxford: Oxbow Books. p 43-59.
McDonald MMA. 2009. Increased sedentism in the central oases of the Egyptian Western Desert in the Early to Mid-Holocene: evidence from the peripheries. African Archaeological Review 26(1):3-43.

Midant-Reynes B, Briois F. 2009. Un site pré-Badarien dans l'oasis de Kharga (Égypte): KS043. In: De Méditerranée et d'ailleurs...Mélanges offerts à Jean Guilaine. Toulouse: College de France. p 533-46.

Pazdur A, Pazdur MF, Zastwny A. 1994. Gliwice radiocarbon dates XII. Radiocarbon 36(2):281-302.

Reimer PJ, Baillie MGL, Bard E, Bayliss A, Beck JW, Blackwell PG, Bronk Ramsey C, Buck CE, Burr GS, Edwards RL, Friedrich M, Grootes PM, Guilderson TP, Hajdas I, Heaton TJ, Hogg AG, Hughen KA, Kaiser KF, Kromer B, McCormac FG, Manning SW, Reimer RW, Richards DA, Southon JR, Talamo S, Turney CSM, van der Plicht J, Weyhenmeyer CE. 2009. IntCal09 and Marine09 radiocarbon age calibration curves, 0-50,000 years cal BP. Radiocarbon 51(4): 1111-50.

Riemer H. 2000. Regenfeld 96/1 Great sand sea and the question of human settlement on whaleback dunes. In: Krzyzaniak L, Kroeper K, Kobusiewicz M, editors. Recent Research into the Stone Age of Northeastern Africa. Studies in African Archaeology. Poznań: Poznań Archaeological Museum. p 21-31.

Riemer H, Kindermann K, Eickelkamp S. 2004. Dating and production technique of Ounan points in the Eastern Sahara. New archaeological evidence from Abu Tartur, Western Desert of Egypt. Nyame Akuma (61): $10-6$.

Schön W. 1996. Ausgrabungen im Wadi el-Akhdar, Gilf Kebir (SW-Ägypten). Köln: Heinrich-Barth Institut.

Stuiver M, Polach HA. 1977. Discussion: reporting of ${ }^{14} \mathrm{C}$ data. Radiocarbon 19(3):355-63.

Vogel JC, Visser E, Fuls A. 2001. Suitability of ostrich eggshell for radiocarbon dating. Radiocarbon 43(1): 133-7.

Wendorf F, Schild R, editors. 1980. Prehistory of the Eastern Sahara. New York: Academic Press.

Wendorf F, Schild R. 2001. Holocene Settlement of the Egyptian Sahara. Volume 1. The Archaeology of Nabta Playa. Dordrecht: Kluwer Academic.

Wendorf F, Schild R. 2004. The Western Desert during the 5th and 4th millennia $\mathrm{BC}$ : the Late and Final Neolithic in Nabta-Kiseiba area. Archéo-Nil 14:1330. 